\title{
KEPUTUSAN PEMBELIAN E-COMMERCE MELALUI KEMUDAHAN PENGGUNAAN, KUALITAS INFORMASI DAN KUALITAS INTERAKSI LAYANAN WEB
}

\author{
Siti Romla \\ Alifah Ratnawati \\ Universitas Islam Sultan Agung Semarang \\ monashadi23@yahoo.com
}

\begin{abstract}
Purchasing decisions become an important thing in retaining customers. The purchase decision is a customer's response to a discrepancy between the level of prior importance and the actual performance it perceives after use. As for the population is a student class of 2013. Samples taken in the study obtained for 96.04 then rounded up to 100 people. Based on the above calculation results, the number of samples taken in this study is the student class of 2013 as many as 100 respondents. Criteria of sampling as a resource is a social networking site users who have made purchases two (2) times through social networking sites. The result of research indicate that Ease, Quality of information, Quality of interaction have positive and significant influence to trust, Ease, Quality of information, Quality of interaction have positive and significant influence to purchasing decision, Trust influence positively and significantly to purchasing decision.
\end{abstract}

Keywords : Ease, Quality of information, Quality of trust interaction, purchase decision.

\section{PENDAHULUAN}

Keputusan pembelian menjadi suatu hal yang penting dalam mempertahankan pelanggan. Keputusan pembelian merupakan respon pelanggan terhadap ketidaksesuaian antara tingkat kepentingan sebelumnya dan kinerja aktual yang dirasakannya setelah pemakaian (Rangkuti, 2012). Menurut Schnaars, pada dasarnya tujuan dari sebuah bisnis adalah menciptakan para pelanggan yang puas. Terciptanya keputusan pembelian dapat memberikan manfaat, diantaranya hubungan antar perusahaan dengan pelanggan menjadi harmonis, memberikan dasar yang baik bagi pelanggan untuk melakukan pembelian ulang. Dan terciptanya keputusan pembelian, dan memberikan rekomendasi yang baik dari mulut ke mulut yang menguntungkan bagi perusahaan.

Faktor-faktor yang mempengaruhi keputusan pembelian salah satunya adalah kepercayaan pelanggan. Menurut Pavlou dan Geffen (2012) Kepercayaan ECommerce adalah hal penting yang dapat mempengaruhi minat pembelian secara online. Faktor kunci dalam setiap pembelian online terdapat pada faktor kepercayaan $E$ Commerce. Transaksi yang terjadi dimedia internet hanya dapat terjadi pada pelanggan yang memiliki kepercayaan E-Commerce dan kebranian dalam mengambil resiko. Oleh karena itu transaksi yang terjadi pada e-commerce tidak akan terjadi apabila tidak adanya kepercayaan E- Commerce yang menjadi landasan, ditambah dengan barang yang dijual di media internet merupakan barang yang masih berupa bayangan dari 
penjual.

Keputusan pembelian dalam penelitian ini juga diperngaruhi oleh kemudahan penggunaan. Persepsi Kemudahan didefinisikan sebagai sejauh mana seseorang percaya bahwa menggunakan suatu teknologi akan bebas dari usaha (Hartono, 2007). Menurut Amijaya (2010) persepsi kemudahan ini akan berdampak pada perilaku, yaitu semakin tinggi persepsi seseorang tentang kemudahan menggunakan sistem, semakin tinggi pula tingkat pemanfaatan teknologi informasi.

Selain kemudahan penggunaan yang perlu diperhatikan dalam bisnis online faktor kualitas informasi juga sangat penting. Kualitas informasi melakat kepada produk atau jasa yang dijual. Informasi yang lengkap dan jujur merupakan hal yang sangat penting dalam melakukan pembelian ataupun penjualan melalui media sosial karena antara penjual dan pembeli tidak saling ketemu dan barang yang diperdagangkan pun hanya bisa dilihat dari foto sehingga kualitas barangpun agak sulit untuk diprediksi apakah sesuai dengan keinginan pembeli. Semakin baik kualitas informasi yang diberikan akan menambah minat pembeli untuk melakukan pembelian secara online (Khairani, 2015). Dari hasil pengujian data yang telah dilakukan oleh Khairani (2015) diperoleh hasil bahwa variabel kualitas informasi berpengaruh positif dan signifikan terhadap keputusan pembelian melalui media sosial. Hasil penelitian ini didukung oleh hasil penelitian yang telah dilakukan oleh (Hardiawan, 2013; Adityo, 2011) bahwa kualitas informasi berpengaruh positif dan signifikan terhadap kesiaan untuk melakukan pembelian. Semakin baik kualitas informasi yang disediakan di media sosial maka akan semakin tinggi kesediaan konsumen untuk melakukan pembelian melalui media sosial.

Faktor lain yang mempengaruhi keputusan pembelian adalah kualitas interaksi layanan. Faktor pendukung e-commerce salah satunya adalah website.
Konsumen pada e-commerce berinteraksi dengan perusahaan menggunakan website. Pengukuran kualitas website dapat dilakukan dengan tools atau survei. Pada penelitian ini, kualitas web diukur oleh pengguna khususnya oleh konsumen dengan didasari oleh pengukuran kualitas website menggunakan webqual 4.0. Pengukuran kualitas web pada webqual 4.0 dilakukan oleh pengguna web tersebut sehingga pengukuran yang dilakukan akan membantu pengelola web untuk menyesuaikan kualitas web sesuai dengan persepsi pengguna. Webqual 4.0 memiliki beberapa variabel yang dapat diukur yaitu kegunaan, kualitas informasi dan kualitas interaksi layanan. Ketiga variabel yang digunakan pada webqual dapat menjawab permasalahan perusahaan e-commerce dalam menjawab kebutuhan pelanggan terhadap kualitas website yang dikelola perusahaan e-commerce (Barnes dan Vidgen, 2012)

Kepercayaan berperan sangat penting dalam membina hubungan, terutama dalam pembelian melalui situs jejaring sosial maupun pada usaha jasa yang penuh dengan risiko dan kurangnya informasi di antara pihak penjual dan pembeli. Kelangsungan suatu usaha sangat tergantung pada tingkat kepercayaan yang dibina antara penjual dan pembeli. Dapat diketahui bahwa ada sebagaian besar transaksi yang dilakukan melalui situs jejaring sosial dapat dilakukan secara langsung seperti pada saat membeli sebuah produk secara langsung di toko. Hal inilah yang membuat pola pikir konsumen menjadi berpikir bahwa ada suatu tanda Tanya besar pada situs jejaring sosial. Karena faktor tersebutlah butuh adanya suatu kepercayaan kepada konsumen agar konsumen menjadi merasa nyaman dan tidak menaruh curiga terhadap penjual online shop dan akhirnya hubungan dan komunikasi yang terjadi antara penjual dan pembeli tidak mudah terganggu. Kepercayaan inilah yang menjadi alat untuk meningkatkan keyakinan konsumen dalam 
menentukan keputusan untuk membeli sebuah prosuk melalui situs jejaring sosial. Semakin maraknya kejahatan yang terjadi pada internet berupa pembobolan, penipuan, dan lain sebagainya faktor kepercayaan menjadi hal yang sangat berperan penting dalam transaksi online shopping. Konsep ini menjadikan pembeli percaya terhadap produk yang ditawarkan oleh penjual melalui online dan dapat menjamin keamaan bertransaksi online. Keamanan berarti bahwa transaksi penjualan online dapat dipercaya oleh konsumen. (Baskara 2014)

Jumlah pengguna Internet di seluruh dunia sampai tahun 2017 diprediksi akan mencapai 3 miliar. Dua pertiganya berasal dari penduduk di negara-negara berkembang. Hal tersebut disampaikan oleh International Telecomunications Union (ITU) dalam laporan terbarunya. Jumlah 3 miliar tersebut sudah sama dengan 40 persen populasi penduduk Bumi. Menurut ITU, penetrasi internet sudah mencapai titik jenuh di negara maju, sementara di negaranegara berkembang, penetrasi internet sedang melaju kencang.

Dilihat dari data statistik diatas menunjukkan bahwa penggunaan internet di Indonesia mulai tumbuh semenjak tahun 1998. Di tahun 1998 pengguna internet di Indonesia hanya 0,5 juta orang. Internet di Indonesia terus menerus meningkat setiap tahunnya hingga menyentuh angka 55 juta pengguna pada tahun 2011 dan 63 juta pengguna di tahun 2012. Menurut Asosiasi Penyelenggara Jasa Internet Indonesia (APJII) mengungkapkan bahwa pada tahun 2013 pengguna internet hanya mencapai 71,19 juta, dari perkiraan yang mencapai 82 juta, akan tetapi jika dibandingkan dengan tahun 2012, maka ada kenaikan sebesar 13\%. Tahun depan, APJII memprediksi pengguna internet naik sekitar 30 persen menjadi 82 juta pengguna dan terus mengalami kenaikan menjadi 107 juta pada 2014 dan 139 juta atau 50 persen total populasi pada 2015.

Menurut International Telecommunication
Union (ITU) pada tahun 2011 pengguna internet global samencapai angka 2,044 miliar dan pada tahun 2015 mengalami kenaikan menjadi 2,421 miliar. Meningkatnya jumlah pengguna internetsendiri telah menarik berbagai macam bisnis untuk mempromosikan produknya di internetdan sekaligus untuk melakukan transaksi perdagangan. Internet mampu mempengaruhi hampir di semua sektor bisnis. Dari mulai perusahaan - perusahaan skala besar hingga online shop kecil pun memanfaatkan internet untuk branding produk, pemasaran, penjualan produk. Sebagian dari pengguna internet Indonesia dan di luar negeri, telah melakukan pembelian online. Dari data di atas menunjukkan bahwa 100 juta pengguna internet merupakan potensi pasar yang besar yang akan mempengaruhi munculnya berbagai peluang bisnis baru. (http://tekno. kompas.com)

Menurut data dari Pew Research Internet Project, Instagram pada tahun 2014 merupakan situs jejaring sosial dengan tingkat perkembangan yang tertinggi.Pada tahun 2013, secara khusus di Indonesia mencatatkan terdapat peningkatan yang tinggi di kalangan para pengguna dewasa. Bahkan saat ini sebanyak 26 persen populasi masyarakat berusia dewasa di Indonesia mempunyai akun Instagram. Jika dibandingkan tahun 2015, terdapat peningkatan sebesar 9 persen. Menurut Baskara (2011) Kepercayaan berpengaruh positif dan signifikan terhadap keputusan pembelian. Sedangkan menurut Jihan ulya alhasanah, Kertahadi dan Riyadi (2014) kepercayaan tidak berpengaruh signifikan terhadap Keputusan Pembelian Online.

\section{TINJAUAN PUSTAKA}

\section{Keputusan Pembelian}

Schiffman dan Kanuk (2012), keputusan pembelian merupakan suatu pilihan dari beberapa alternatif yang ada.Ada beberapa tipe perilaku keputusan dalam membeli. Semakin kompleks keputusan 
biasanya akan melibatkan semakin banyak pihak yang terkait dan semakin banyak pertimbangan. Empat jenis perilaku pembelian menurut Kotler (2014) antara lain : Perilaku pembelian yang rumit Konsumen terlibat dalam perilaku pembelian yang rumit bila mereka terlibat dalam pembelian dengan perbedaan merek. Perilaku pembelian pengurangan ketidaknyamanan. Kadang-kadang konsumen sangat terlibat dalam pembelian namun melihat sedikit perbedaan antar merek. Keterlibatan yang tinggi disadari oleh fakta bahwa pembelian tersebut mahal, jarang dilakukan dan berisiko. Perilaku pembelian karena kebiasaan. Banyak produk dibeli pada kondisi rendahnya keterlibatan konsumen dan tidak adanya perbedaan antar merek yang signifikan. Perilaku pembelian yang mencari variasi. Beberapa situasi pembelian ditandai oleh keterlibatan konsumen yang rendah tetapi perbedaan antar merek signifikan. Dalam situasi ini, konsumen sering melakukan peralihan mrek. Peralihan merek terjadi karena mencari variasi dan bukannya karena ketidakpuasan.

Hal ini menyimpulkan bahwa ada beberapa jenis perilaku dalam keputusan pembelian, yang masing-masing perilaku konsumen dipengaruhi oleh kebiasaan, merk, situasi, dan juga banyaknya pilihan alternatif yang ada. Pengambilan keputusan merupakan suatu kegiatan individu yang secara langsung terlibat dalam mendapatkan dan mempergunakan barang yang ditawarkan. Tahap-tahap proses keputusan pembelian (Kotler, 2012) : Pengenalan Masalah (Problem Recognition). Pengenalan masalah yang ada dapat terjadi baik dari dalam diri maupun dari pihak luar, hal ini terjadi apabila terdapat perbedaan antara keadaan yang sebenarnya terjadi dengan keadaan yang diharapkan atau diinginkan oleh seseorang. Pencarian informasi dibutuhkan oleh konsumen pada saat timbul keinginan dalam memilih suatu produk sehingga pada saat memilih konsumen memiliki beberapa informasi baik dari segi harga dan kualitas. Penilaian alternatif dilakukan setelah tahap pencarian informasi, penilaian alternatif ini dilakukan agar konsumen lebih mengerti dan sadar akan resiko dalam pembelian baik dari segi resiko harga maupun resiko kualitas. Pada tahap ini konsumen menentukan dan mengambil keputusan apakah jadi membeli atau tidak setelah mempertimbangkan tahap yang telah dilewati. Perilaku pasca pembelian terdapat tingkat kepuasan atau tidak puas, dikarenakan setelah membeli konsumen baru menyadari bahwa barang yang telah dibeli memiliki harga yang lebih mahal dibandingkan dengan tempat lainnya.

Indikator yang digunakan adalah pemilihan terhadap produk, mempunyai manfaat, 3. sesuai kebutuhan, pembelian berulang, memberikan rekomendasi kepada orang lain (Thomson, 2013).

\section{Kemudahan Penggunaan}

Perceived ease of use didefinisikan Chin dan Todd (2011) mengemukakan seberapa besar kemudahan dalam menggunakan komputer untuk dimengerti dan dipahami. Bagaimana cara transaksi atau operasional berbelanja secara onlinr merupakan salah satu faktor kemudahan yang berkaitan. Calon pembeli secara online pertama kali dalam berbelanja merasa faktor keamanan tidak terpenuhi dan tidak tahu cara bertransaksi hal ini dapat mempengaruhi keputusan calon pembeli tersebut. Jika dikaitkan dengan sistem berbelanja online, kemudahan disini dapat diartikan bahwa pembeli merasa tidak mengalami kesulitan pada saat melakukan proses berbelanja online. Pembeli online percaya bahwa situsonline shopping yang mudah pengoperasiannya, mudah dipahami, mudah dipelajari merupakan karakteristik kemudahan.

Indikator yang digunakan adalah : Mudah untuk dipelajari, mudah untuk digunakan, mudah melakukan transaksi, mudah memperoleh apa yang diinginkan pengguna (Davis et al,2012).

Hasil studi menunjukkan kemudahan 
penggunaan berpengaruh positif dan signifikan terhadap kepercayaan (Sam dan Tahir 2011). Oleh karena itu hipotesis yang diajukan adalah :

$\mathrm{H} 1$ : kemudahan penggunaan berpengaruh positif dan signifikan terhadap kepercayaan.

Hasil penelitian oleh Suhir dkk (2014) mengatakan bahwa pengaruh positif tentang kemudahan memiliki pangaruh yang signifikan terhadap keputusan yang dipilih oleh pembeli

Oleh karena itu hipotesis yang diajukan adalah:

$\mathrm{H} 4$ : kemudahan penggunaan berpengaruh positif dan signifikan terhadap keputusan pembelian.

\section{Kualitas Informasi}

Informasi kualitas jasa pada online shopping terdiri dari informasi pemesanan, informasi pengiriman, dan promosi yang ditawarkan (Suhir, dkk 2014).

Kualitas informasi E- Commerce (quality of information) dipengaruhi 3 faktor yang penting, yaitu relevansi, akurasi dan ketepatan waktu. Relevansi (relevancy) berkualitasnya suatu informasi yang disajikan tergambarkan apabila informasi tersebut relevan bagi pemakainya. Akuratnya suatu informasi ditandai dengan informasi yang disajikan tidak menyesatkan, menyesatkan dalam arti bebas dari kesalahan serta dapat menjelaskan apa yang dimaksud. Sumber informasi data dapat mengalami suatu gangguan yang tidak disengaja maupun disengaja yang berdampak pada perubahan data asli hal ini menimbulkan ketidak akuratan sebuah informasi.

Indikator yang digunakan adalah sebagai berikut : Informasi yang diberikan untuk suatu produk telah menggambarkan produk yang diinginkan pembeli informasi mudah dimengerti, Informasi up to date, Informasi akurat. (Sukma, Abdurrahman Adi, 2012).

Hasil studi menunjukkan kualitas informasi berpengaruh positif dan signifikan terhadap kepercayaan (Indriani dan Nurcaya, 2015). Oleh karena itu hipotesis yang diajukan adalah:

$\mathrm{H} 2$ : kualitas informasi berpengaruh positif dan signifikan terhadap kepercayaan.

Hasil penelitian oleh Ulya (2014) menunjukkan bahwa kualitas informasi berpengaruh positif dan signifikan terhadap keputusan pembelian. Oleh karena itu hipotesis yang diajukan adalah:

H5 : kualitas informasi berpengaruh secara positif terhadap keputusan pembelian melalui situs jejaring sosial.

\section{Kualitas Interaksi \\ Menurut Sukma (2011) menyatakan} bahwa kualitas interaksi berpengaruh terhadap kepercayaan pelanggan. Sukma (2011) mengemukakan mengenai kualitas interaksi layanan web E-Commerce yaitu dampak apa yang akan di terima oleh konsumen ketika melakukan transaksi secara online dimasa depan.

Kualitas interaksi (interaction quality), kualitas lingkungan fisik (physical environment quality) dan kualitas hasil (outcome quality). Komponen - komponen tersebut dapat dijabarkan dengan dimodifikasi sesuai dengan jenis usaha yang diteliti dan kemudian dijadikan kriteriakriteria penilaian bagi pelanggan terhadap kinerja perusahaan. Dapat disimpulkan bahwa kualitas interaksi berpengaruh terhadap kepercayaan pelanggan.

Hasil studi menunjukkan kualitas interaksi layanan web berpengaruh positif dan signifikan terhadap kepercayaan pelanggan (Barnes dan Vidgen 2014). Oleh karena itu hipotesis yang diajukan adalah :

H3 : kualitas interaksi layanan web berpengaruh positif dan signifikan terhadap Kepercayaan Pelanggan

Hasil studi menunjukkan kualitas interaksi berpengaruh positif dan signifikan terhadap keputusan pembelian (Suhari, 2012). Oleh 


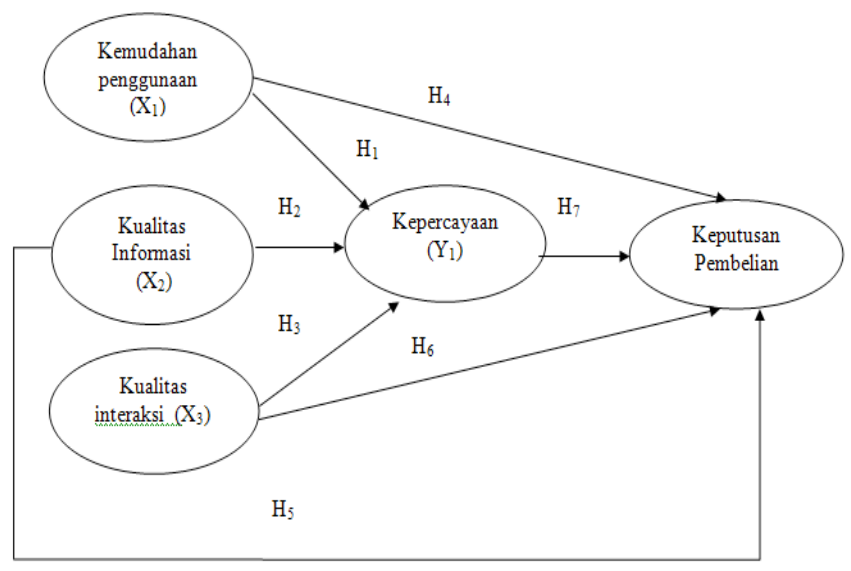

Gambar 1. Model Empirik

karena itu hipotesis yang diajukan adalah:

H6 : kualitas interaksi berpengaruh secara positif terhadap keputusan pembelian

\section{Kepercayaan}

Hal utama yang menjadi pertimbangan seseorang akan berbelanja pada situs online yaitu kepercayaan E- Commerce. Mereka akan memutuskan untuk membeli produk tersebut atau tidak dilihat dari popularitas situs online shopping tersebut. Pembeli akan lebih percaya jika situs tersebut lebih populer karena yakin dan percaya terhadap reliabilitas situs tersebut.

Indikator yang digunakan adalah kesesuaian produk yang dipesan, lama waktu pengiriman dan kekhawatiran keamanan produk, tidak nyaman secara psikologis (Suresh A.M. dan Shashikala R. 2011).

Hasil penelitian oleh Baskara (2014) dan Ardyanto (2015) menunjukkan bahwa kepercayaan berpengaruh positif dan signifikan berdasarkan keputusan pembelian Oleh karena itu hipotesis yang diajukan adalah:

$\mathrm{H} 7$ : Kepercayaan berpengaruh positif dan signifikan terhadap keputusan pembelian.

\section{METODE PENELITIAN}

Jenis penelitian yang digunakan dalam penelitian ini adalah analisis explanatory research atau penelitian yang bersifat menjelaskan. Metode ini berusaha untuk menjelaskan serta menyoroti hubungan atau pengaruh variabel yang diajukan dalam penelitian dan menguji hipotesis yang telah dirumuskan.

Populasi dalam penelitian ini adalah mahasiswa Unissula angkatan 2013 yang menggunakan e-commerce. Sampel yang diambil sebanyak 100 responden dengan menggunakan teknik purposive sampling yang artinya pengambilan sampel dengan mempertimbangkan karakteristik populasi yaitu para konsumen yang sudah pernah melakukan transaksi pembelian 2 kali melalui situs jejaring social. Sumber data adalah data primer yang digunakan pada penelitian ini diperoleh melalui kuesioner yang diberikan secara langsung kepada responden untuk memperoleh informasi, yaitu memberikan daftar pertanyaan yang telah disusun sebelumnya untuk dijawab oleh responden mengenai pengaruh kemudahan penggunaan, kualitas informasi, kualitas interaksi, kepercayaan dan keputusan pembelian. Lalu Data sekunder adalah data yang diperoleh melalui data yang telah diteliti dan dikumpulkan oleh pihak lain yang berkaitan dengan permasalahan penelitian. Data sekunder diperoleh melalui kepustakaan, yaitu pengumpulan data yang berasal dari buku-buku literatur serta bacaan-bacaan lain yang berhubungan 
dengan pemasaran dan perilaku konsumen.

Metode pengumpulan data melalui observasi, wawancara dan kuesioner.

\section{HASIL DAN PEMBAHASAN \\ Deskripsi Variabel}

Berdasarkan hasil penelitian pada pengguna e-commerce melalui situs jejaring sosial masing-masing deskripsi variabel adalah sebagai berikut:

\section{Kemudahan Penggunaan}

Secara rinci tanggapan responden tertinggi yaitu pada indikator proses pemesanan produk pada situs jejaring social mudah dipelajari dengan nilai ratarata sebesar 3,43 , sedangkan tanggapan terendah yaitu pada indikator proses melakukan transaksi pada situs jejaring social mudah untuk dilakukan dengan nilai rata-rata sebesar 3,27.

\section{Kualitas Informasi}

Secara rinci tanggapan tertinggi yaitu pada indikator informasi produk yang disampaikan menggambarkan produk yang diinginkan yaitu dengan nilai rata-rata sebesar 4,16, sedangkan untuk tanggapan terendah yaitu pada indikator informasi yang disampaikan up to date dengan rata-rata sebesar 3,70. Dengan begitu situs jejaring sosial harus tetap memberikan informasi yang terkini agar para konsumen mudah mencari produk yang diinginkan.

\section{Kualitas Interaksi}

Secara rinci tanggapan responden tertinggi yaitu pada indikator lama waktu pengiriman yaitu nilai rata-rata sebesar 4,50 , sedangkan tanggapan terendah yaitu pada indikator rasa ketakutan konsumen saat melakukan pembelian yaitu dengan skor rata-rata sebesar 3,99.

\section{Kepercayaan}

Secara rinci tanggapan responden tertinggi yaitu pada indikator jaminan kepuasan yaitu nilai rata-rata sebesar 4,05, sedangkan tanggapan terendah yaitu pada indikator pihak penjual memenuhi janjijanjinya dengan nilai rata-rata sebesar 3,91.

\section{Keputusan Pembelian}

Secara rinci tanggapan tertinggi yaitu pada indikator produk mampu memenuhi kebutuhan konsumen dengan rata-rata sebesar 4,05, sedangkan untuk tanggapan terendah yaitu pada indikator melakukan pembelian kembali karena memenuhi criteria pembeli dengan nilai rata-rata sebesar 3,46.

\section{Uji Validitas}

Berdasarkan hasil perhitungan dengan SPSS, masing-masing variabel kemudahan penggunaan, kualitas informasi, kualitas interaksi, kepercayaan dan keputusan pembelian , hasil yang diperoleh menunjukkan valid. Hal ini dibuktikan dengan semua nilai hasil $r$ hitung pada semua indikator variabel tersebut diperoleh melebihi nilai $r$ tabel sebesar 0,197 dengan signifikansinya di bawah tingkat kesalahan sebesar 0,05. Maka kuesiner dalam penelitian ini adalah valid

\section{Uji Reliabilitas}

Berdasarkan perhitungan dengan program SPSS masing-masing variabel mempunyai nilai $>0.6$ alpha, maka kuesioner dalam penelitian ini adalah konsisten atau reliabel.

\section{Uji Kelayakan Model}

Berdasarkan hasil uji koefisien determinasi $\left(\mathrm{R}^{2}\right)$ dengan melihat Adjusted $R$ Square. Jika Adjusted $R^{2}$ yang diperoleh dari hasil perhitungan semakin besar (mendekati satu), maka dapat dikatakan bahwa sumbangan dari variabel bebas terhadap terikat semakin besar.

Nilai koefisien determinasi antara kemudahan penggunaan, kualitas informasi, kualitas interaksi, terhadap kepercayaan yang ditunjukkan dengan nilai Adjusted $R$ Square sebesar 0,577 , dapat diartikan bahwa kepercayaan mampu dijelaskan 
oleh ketiga variable yaitu kemudahan penggunaan, kualitas informasi dan kualitas interaksi sebesar $57,7 \%$ sedangkan sisanya dijelaskan oleh variabel lain yang tidak diamati dalam penelitian ini.

Nilai koefisien determinasi antara kemudahan penggunaan, kualitas informasi, kualitas interaksi, dan kepercayaan terhadap terhadap keputusan pembelian ditunjukkan dengan nilai Adjusted $R$ Square sebesar 0,862 , dapat diartikan bahwa keputusan pembelian mampu dijelaskan oleh keempat variabel yaitu kemudahan penggunaan, kualitas informasi, kualitas interaksi, dan kepercayaan sebesar $86,2 \%$ sedangkan sisanya dijelaskan oleh variabel lain yang tidak diamati dalam penelitian ini.

\section{Uji Multikolinearitas}

Hasil perhitungan menunjukkan bahwa tolerance diatas $10 \%$ dan VIF dibawah 10 , maka dapat disimpulkan bahwa asumsi tidak ada multikolinearitas dalam penelitian ini terpenuhi.

\section{Regresi dengan Metode Path Analysis}

Berdasarkan pada persamaan regresi pengaruh tidak langsung antara kemudahan penggunaan, kualitas informasi, kualitas interaksi terhadap kepercayaan dapat dijelaskan sebagai berikut:

$$
Y_{1}=0,113 X_{1}+0,484 X_{2}+0,520 X_{3}
$$

Nilai koefisien regresi untuk variabel kemudahan penggunaan, kualitas informasi, kualitas interaksi menunjukan nilai positif, berarti jika variabel tersebut meningkat maka variabel kepercayaan akan meningkat.

Berdasarkan pada persamaan regresi pengaruh langsung antara kemudahan penggunaan, kualitas informasi, kualitas interaksi dan kepercayaan terhadap keputusan pembelian dapat dijelaskan sebagai berikut:

$$
Y_{2}=0,666 X_{1}+0,241 X_{2}+0,169 X_{3}+
$$

Nilai koefisien regresi untuk variabel kemudahan penggunaan, kualitas informasi, kualitas interaksi dan kepercayaan menunjukan nilai positif, berarti jika variabel tersebut meningkat maka variabel keputusan pembelian akan meningkat.

\section{Pengujian Hipotesis \\ Pengaruh Kemudahan Terhadap Kepercayaan}

Hasil pengujian hipotesis menunjukkan bahwa nilai $\mathrm{t}$ hitung untuk kemudahan adalah 2,254 dengan signifikansinya sebesar 0,026 , sedangkan pada taraf signifikansi sebesar 0,025 dengan df sebesar $=95$ diperoleh nilai t tabel sebesar 1,985 sehingga nilai t hitung $=2,254$ $>$ nilai $\mathrm{t}$ tabel $=1,985$. Dengan demikian menunjukkan bahwa ada pengaruh yang signifikan antara kemudahan terhadap kepercayaan $(\mathrm{Y})$.

\section{Pengaruh Kualitas Informasi Terhadap Kepercayaan}

Hasil pengujian hipotesis dengan menggunakan SPSS diperoleh nilai t hitung untuk kualitas informasi adalah 8,904 dengan signifikansinya sebesar 0,000 , sedangkan nilai $t$ tabel diketahui sebesar 1,985 sehingga nilai $t$ hitung $=8,904>$ nilai $\mathrm{t}$ tabel $=1,985$. Hal ini menunjukkan bahwa terdapat pengaruh signifikan antara kualitas informasi terhadap keputusan pembelian (Y).

\section{Pengaruh Kualitas Interaksi Terhadap Kepercayaan}

Hasil pengujian hipotesis menunjukkan bahwa nilai t hitung untuk kualitas interaksi adalah 9,676 dengan signifikansinya sebesar 0,000 sedangkan pada taraf sebesar 0,025 dengan $\mathrm{df}$ sebesar $=95$ diperoleh nilai $\mathrm{t}$ tabel sebesar 1,987 sehingga nilai t hitung $=9,676>$ nilai $t$ tabel $=1,987$. Dengan demikian menunjukkan bahwa terdapat pengaruh signifikan antara kualitas interaksi terhadap kepercayaan pelanggan. 


\section{Pengaruh Kemudahan Terhadap \\ Keputusan Pembelian}

Hasil pengujian hipotesis menunjukkan bahwa nilai t hitung untuk kemudahan adalah 21,570 dengan signifikansinya sebesar 0,000 , sedangkan pada taraf signifikansi sebesar 0,025 dengan $\mathrm{df}$ sebesar $=95$ diperoleh nilai $\mathrm{t}$ tabel sebesar 1,985 sehingga nilai t hitung $=21,570>$ nilai $t$ tabel $=1,985$. Dengan demikian menunjukkan bahwa ada pengaruh yang signifikan antara kemudahan terhadap keputusan pembelian (Y).

\section{Pengaruh Kualitas Informasi Terhadap Keputusan Pembelian}

Hasil pengujian hipotesis dengan menggunakan SPSS diperoleh nilai t hitung untuk kualitas informasi adalah 5,490 dengan signifikansinya sebesar 0,000 , sedangkan nilai $\mathrm{t}$ tabel diketahui sebesar 1,985 sehingga nilai t hitung $=5,490>$ nilai $\mathrm{t}$ tabel $=1,985$. Hal ini menunjukkan bahwa terdapat pengaruh signifikan antara kualitas informasi terhadap keputusan pembelian $(\mathrm{Y})$.

\section{Pengaruh Kualitas Interaksi Terhadap Keputusan Pembelian}

Hasil pengujian hipotesis menunjukkan bahwa nilai t hitung untuk kualitas interaksi adalah 3,729 dengan signifikansinya sebesar 0,000 sedangkan pada taraf sebesar 0,025 dengan df sebesar $=95$ diperoleh nilai $t$ tabel sebesar 1,987 sehingga nilai t hitung $=3,729>$ nilai $t$ tabel $=1,987$. Dengan demikian menunjukkan bahwa terdapat pengaruh signifikan antara kualitas interaksi terhadap keputusan pembelian $(\mathrm{Y})$.

\section{Pengaruh Kepercayaan Terhadap Keputusan Pembelian}

Hasil pengujian hipotesis menunjukkan bahwa nilai $t$ hitung untuk kepercayaan adalah 3,217 dengan signifikansinya sebesar 0,002 sedangkan pada taraf sebesar $5 \%$ dengan df sebesar $=95$ diperoleh nilai $t$ tabel sebesar 1,985 sehingga nilai t hitung
$=3,217>$ nilai $t$ tabel $=1,985$. Dengan demikian menunjukkan bahwa terdapat pengaruh signifikan antara kepercayaan terhadap keputusan pembelian $(\mathrm{Y})$.

\section{Pengaruh Langsung Dan Tidak Langsung}

Untuk mengetahui pengaruh langsung dan tidak langsung antara kemudahan penggunaan, kualitas informasi, kualitas interaksi dan kepercayaan terhadap keputusan pembelian dapat dijelaskan dengan menggunakan uji SPSS. Adapun kriteria dikatakan mampu menjadi variabel intervening dapat dilihat pada nilai $p$-value $<$ taraf signifikansi 0,05 , yang berarti Ho ditolak dan Ha diterima yang berarti ada pengaruh signifikan.

\section{Pengaruh kemudahan Penggunaan terhadap Keputusan Pembelian melalui Kepercayaan E- Commerce.}

Hasil pengujian SPSS antara kemudahan penggunaan terhadap keputusan pembelian dengan kepercayaan sebagai variabel intervening, maka diperoleh nilai sebesar 0,022 . Dengan hasil tersebut berarti nilai $P$-valuenya lebih kecil dari tingkat kesalahan sebesar 0,05 , yang berarti bahwa kepercayaan mampu menjadi variabel intervening antara kemudahan penggunaan dengan keputusan pembelian, dapat diartikan bahwa semakin baik kemudahan penggunaan pada suatu situs jejaring sosial maka akan semakin tinggi pula keputusan pembelian konsumen yang mana kepercayaan pelanggan akan mempengaruhi dari keputusan pembelian konsumen itu sendiri.

\section{Pengaruh Kualitas Informasi Terhadap keputusan pembelian melalui kepercayaan}

Berdasarkan perhitungan diatas maka hasil dalam penelitian ini adalah terdapat pengaruh langsung antara kemudahan penggunaan terhadap keputusan pembelian yaitu 0,241 lebih besar daripada kualitas 
infoamsi ke keputusan pembelian melalui kepercayaan yaitu sebesar 0,095, maka variabel kepercayaan merupakan variabel intervening.

\section{Pengaruh Kualitas Interaksi Terhadap keputusan pembelian melalui kepercayaan}

Berdasarkan perhitungan diatas maka hasil dalam penelitian ini adalah terdapat pengaruh langsung antara terhadap keputusan pembelian yaitu 0,169 lebih besar daripada kualitas interaksi ke keputusan pembelian melalui kepercayaan yaitu sebesar 0,102, maka variabel kepercayaan merupakan variabel bukan intervening

\section{SIMPULAN}

Berdasarkan penelitian yang telah dilakukan maka dapat diperoleh kesimpulan sebagai berikut :

Semakin tinggi kemudahan yang diperoleh pelanggan maka akan semakin tinggi pula tingkat kepercayaan. Dengan adanya internet masyarakat memperoleh kemudahan informasi dan berita yang sedang booming di dunia sehingga masyarakat tahu apa saja yang sedang terjadi. Kemudahan dapat diandaikan bahwa pengetahuan pembeli tentang online shop tidak dipersulit ketika pembeli hendak melakukan pembelanjaan online dibandingkan dengan pembeli yang sama sekali tidak memiliki pengetahuan.

Online shop harus menyajikan informasi yang mencangkup seluruh produk dan jasa yang akan ditawarkan oleh konsumen. Informasi tersebut harus berguna dan relevan dalam memprediksi kegunaan serta kualitas dari produk atau jasa yang akan ditawarkan. Informasi yang disajikan oleh konsumen atau pembeli harus up to date sehingga pembeli merasa puas dengan kebutuhan informasi yang mereka peroleh. Informasi tersebut berguna untuk membantu pembeli membuat keputusan.

Kualitas interaksi layanan berhubungan mengenai reputasi situs, keamanan dalam transaksi, keamanan kerahasiaan informasi pribadi, rasa personalisasi, adanya komunitas, komunikasi dengan perusahaan dan kesesuaian pesanan.

Kemudahan akan mengurangi usaha (baik waktu dan tenaga) seseorang di dalam mempelajari sistem online. Jika dianalogikan pada sistem berbelanja online (online shopping), kemudahan dapat diindikasikan bahwa pembeli yang memiliki pengetahuan tentang online shopping tidak mengalami kesulitan ketika berbelanja online dibandingkan pembeli yang tidak memiliki pengetahuan tersebut. Pembeli online percaya bahwawebsite online shopping yang lebih fleksibel, mudah dipahami dan mudah engoperasiannya (compartible) sebagai karakteristik kemudahan

Website online shopping sebaiknya menyediakan fasilitas kepada konsumen atau pembeli online untuk dapat membuat testimonial atau pernyataan terkait dengan produk atau jasa pada online shopping. Hal ini berguna untuk pembeli online lainnya untuk mengetahui pengalaman pembeli sebelumnya terhadap penjual online dan produk yang dijual oleh penjual online tersebut. Kemudian, website online shopping sebaiknya juga menyediakan laporan evaluasi tentang jenis produk yang laris ataupun kurang peminatnya, penjual yang "lapaknya" laris maupun yang tidak laku

Kualitas interaksi berpengaruh secara positif dan signifikan terhadap keputusan pembelian, artinya semakin tinggi pemahaman kualitas interaksi maka semakin tinggi pula tingkat keputusan pembelian. Tantangan pada bisnis yang sudah menerapkan e-commerce adalah harus selalu memahami kebutuhan konsumen ketika berinteraksi dengan mereka pada sebuah situs web. Untuk itu diperlukan pengukuran kualitas suatu web. Kualitas suatu web juga berpengaruh pada keputusan pembelian oleh konsumen yang dilakukan secara online. Hal ini dapat dilihat pada penelitian Nuseir dkk (2009) bahwa 
e-promosi, keamanan dan infrastruktur pada web mempengaruhi keputusan pembelian online

Untuk dapat mempertahankan hubungan jangka panjang dengan para pembelinya, pihak penjual online perlu menganut konsep kepuasan pelanggan (costumer satisfaction). Agar dapat bertahan hidup dalam era online shopping, pihak penjual online harus mempunyai pelanggan loyal (customer loyality) yang percaya terhadap ekselensi jasa online shopping.

Atas dasar kesimpulan yang telah dikemukakan di atas, dapat diberikan beberapa saran yang diharapkan dapat meningkatkan keputusan pembelian. Adapun beberapa saran tersebut adalah :

Penjualan secara online akan semakin dipercaya oleh konsumen apabila diberi berbagai fasilitas layanan sehingga memudahkan konsumen dalam melakukan aktivitas hubungan / transaksi dengan perusahaan.

Informasi melalui toko online yang disajikan dengan baik dan benar akan memberikan image yang baik terhadap toko tersebut, oleh karena itu keseriusan dalam mengelola toko secara online sangat ditekankan.

Penelitian ini hanya mengkaji pengaruh kepercayaan, kemudahan, kualitas informasi, kualitas interaksi dan keputusan pembelian saja sehingga memungkinkan perbedaan hasil dan kesimpulan apabila dilakukan untuk objek yang berbeda.

Penelitian ini hanya menggunakan metode survey melalui kuesioner, tanpa melakukan wawancara dan terlibat langsung dalam aktivitas instansi, sehingga simpulan yang dikemukakan hanya berdasarkan pada data yang terkumpul melalui instrument msehingga dalam pengisian kuesioner belum maksimal dalam menjawab.

\section{DAFTAR PUSTAKA}

Armstrong, M. (2012). Performance Management. England: Clays,Ltd,St.Ivesple

Barnett, B.R. and Bradley, R. (2007). The Impact of Organizational Support for Career Development on Career Satisfaction. Career Development International, 12 (7) : 617636.

Bogner Bateman, T.S. and Thomas Crant, J.M. (2012). The Proactive Component of Organizational Behaviour. Journal of Personality and Soclal Psychology, 14 : 103-18.

Dessler, G. (2013). Manajemen Personalia. Edisi 3. Terjemahan Agus Dharma. Jakarta: Erlangga.

Ezra, J. (2013). Working With Your Heart, www.powercharacter.com

Husein Umar. (2014). Metode Penelitian Aplikasi DalamPemasaran. PT. Gramedia Pustaka Utama : Jakarta.

Imam Ghozali. (2013). Aplikasi Analisis Multivariate Dengan Program SPSS. UNDIP : Semarang. Kistyanto. A. (2013). Pengaruh Klik Sosial dan Koneksi Terhadap Kesuksesan Karir Hirarki. Jurnal Manajemen dan Kewirausahaan, 10 (1) : 84-92.

Mathis, Robert L. dan Jackson, John H. (2012). Human Resources Management, 9th edition, South-Western, Ohio - Penerjemah: Jimmy Sadeli dan Bayu Prawira Hie, 2009, Penerbit Salemba Empat, Jakarta.

Nurjayanti, V. (2013). Perencanaan Karir dan Manajemen Karir Sebagai Anteseden Hubungan Antara Pengembangan Karir dengan Kepuasan Kerja dan Komitmen Karir (Studi pada PT. BNI Persero Kantor Cabang di Surakarta). Universitas Sebelas Maret Surakarta. Skripsi : tidak dipublikasikan. 
Oliver Valentino Sitorus. (2013). Pengaruh Pengembangan Karir dan Kompetensi terhadap Kepuasan Kerja pada Kantor Pusat Teknologi Nuklir dan Radiometri (PTNBR) Bandung. e-jurnal Universitas Komputer Indonesia.

Pathak, Deepti. (2012). Role of perceived organizational support on stress-sat Pathak isfaction relationship: An empirical study. Asian Journal Of Management Research, 3 Issue 1 : 88-95.

Seibert, S.E. and Kraimer, M.L. (2013). The Five-Factor Model of Personality and Career Success. Journal of Vocational Behavior, $58: 1-21$.

Singarimbun, Masri dan Efendi, Soffyan. (2014). Metodologi Penelitian Survey. LP3ES : Jakarta.

Spencer, LM \& Spencer, SM. 2013. Competence at Work Models for Superior Performance. John Wiley \& Sons, Inc. New York.

Sugiyono, 2010, Metodelogi Penelitian Bisnis, Alfa Beta, Bandung.

T. Hani Handoko. 2013. Manajemen Personalia Dan Sumber Daya Manusia. BPFE. Yogyakarta. Vos, De, Ans et al. (2011). Competency Development and Career Success: The Mediating Role of Employability. Journal of Vocational Behavior, $79: 438-447$.

Winarni, D. (2013). Pengaruh Kepribadian Proaktif Terhadap Kesuksesan Karir Dengan Faktor Demografi, Human Capital, dan Motivasi sebagai Variabel Kontrol (Studi pada Dosen Fakultas Ekonomi Universitas Sebelas Maret Surakarta). Universitas Sebelas Maret Surakarta. Skripsi: tidak dipublikasikan.

Yuliantini, et al. (2013). Determinasi Kompetensi, Komitmen, dan Dukungan Organisasi terhadap Pengembangan Profesi Dosen di Lingkungan Yayasan Triatma Surya Jaya Bandung. e-Journal Program Pascasarjana Universitas Pendidikan Ganesha, 4.

Yuwono dan Ibnu Khajar. (2012). Analisis Beberapa Faktor Yang Mempengaruhi Kepuasan Kerja Pegawai Kejaksaan Tinggi di Yogyakarta, JRBI, 1 (1). 